\title{
414
}

\section{the iolva}

revielv

FALL 1973

POETRY

John R. Carpenter

Sandra McPherson

Ronald Wallace

George Barlow

Wendy Louise Parrish

Mark Halperin

Lewis Gerber

Norman Dukes

John B. Rosenman

Ellen Wittlinger

Joe David Bellamy

Mary Gordon

Kay Deeter

\section{FICTION}

Robert Canzoneri

Robert R. Hellenga

Stuart Dybek

\section{CRITICISM}

A Symposium of Young Poets:

Jon Anderson, Norman

Dubie, Louise Glück,

Thomas Lux, Jack Myers,

Gregory Orr, Stanley

Plumly, Maura Stanton,

James Tate and James

Welch

Introduced and edited by

Michael Ryan, with a

comprehensive essay by

Merle E. Brown 
Volume 4 Number 4

Contents the iolva reviev

Fall 1973

\begin{tabular}{|c|c|c|c|}
\hline \multirow[t]{20}{*}{ POETRY } & John R. Carpenter & The Wires & 4 \\
\hline & Sandra McPherson & Myself & 5 \\
\hline & & Silver & 5 \\
\hline & Ronald Wallace & One Hook & 6 \\
\hline & & Bat & 7 \\
\hline & George Barlow & In Trane, in the Groove & 8 \\
\hline & Wendy Louise Parrish & Parts & 12 \\
\hline & Mark Halperin & The Alarm & 12 \\
\hline & Lewis Gerber & Waiting & 13 \\
\hline & & Shelter Forest & 13 \\
\hline & Norman Dukes & The Parts of Speech & 14 \\
\hline & & Double Negative & 15 \\
\hline & & Dwarves and Flamingoes & 16 \\
\hline & John B. Rosenman & Mirage & 18 \\
\hline & Ellen Wittlinger & Our Separate Trips to the Ocean & 19 \\
\hline & Joe David Bellamy & Plane Crashing Over Boston & 20 \\
\hline & & One Reader Writes: & 21 \\
\hline & Mary Gordon & Nights of Cabiria & 22 \\
\hline & & The Fear of Women, the Fear of Men & 23 \\
\hline & Kay Deeter & Keys in the Car & 25 \\
\hline \multirow[t]{3}{*}{ FICTION } & Robert Canzoneri & The Boot & 28 \\
\hline & Robert R. Hellenga & Russian Dreams & 40 \\
\hline & Stuart Dybek & Blanche: A Baker's Dozen & 45 \\
\hline \multirow[t]{3}{*}{ CRITICISM } & & A Symposium of Young Poets & 52 \\
\hline & & Next Issue & 127 \\
\hline & & Notes on Contributors & 128 \\
\hline
\end{tabular}


In the face of increased production costs, TIR must raise its subscription rates. Effective January 1, 1974, the annual subscription rate will be $\$ 7.50$. All subscriptions received before January 1st will be entered at the current rates. A subscription form is on the final page.

The Iowa Review is a literary quarterly sponsored and published by the School of Letters and the Graduate College of The University of Iowa and printed by The University of Iowa Printing Service.

Copyright (C) 1973, by The University of Iowa.

Second class postage paid at Iowa City, Iowa $\mathbf{5 2 2 4 2}$.

Send subscriptions to the Department of Publications, The University of Iowa, Iowa City, Iowa 52242.

Manuscripts should be sent, with a self-addressed, stamped envelope, to The Iowa Review, EPB 453, The University of Iowa, Iowa City, Iowa 52242.

Merle E. Brown, Editor Jon A. Jackson, Managing Editor Michael Ryan, Associate Editor Helen Chasin, Poetry Editor David Hayman, Fiction Editor Susan Engberg, Editorial Assistant

Statement, in accordance with Postal Manual Section 132.611, of The Iowa Review, published March, June, September, and December, at Iowa City, Iowa 52242, for December 1, 1973. The publisher is The University of Iowa, the editor is Merle E. Brown, Iowa City, lowa, and the business manager is Norman Sage, Iowa City, Iowa. The publication is owned by The University of Iowa, a nonprofit educational institution of the State of Iowa. The average number of copies distributed is $\mathbf{8 0 0}$. 

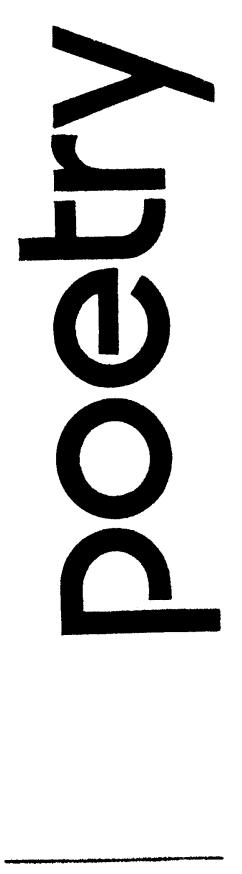


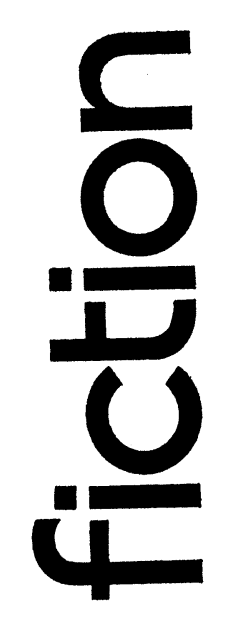




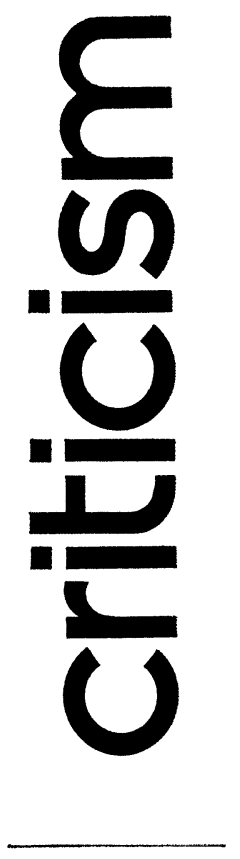

